day, while we were busy preparing intravenous pyelography for him, he suddenly vomitted gross blood several times with severe pains in his stomach. Immediately we trea ted him with Ringer's solution, blood transfusion and injected a heart stimulant, absolute rest in bed was maintained and restlessness was controled by the use of morphin; but his condition deteriorated and died early next morning. Because symptoms were differrent from acute peritonitis, we got $500 \mathrm{cc}$. of hemorrhagic fluid by gastric aspiration before his death.

After his death autopsy was performed, and pathologic changes were noted in the lungs, stomach, kidneys, liver, spleen; pleura and pericardium. They were hemorrhagic and infiltrations and degenerative changes. Macroscopic stone formation was not found in the urinary tract, but micrscopically it was found many small stones in the tiss'de of kidneys.

Examination of the blood disclosed a red cell count of 4,250,000 with a hemoglobin of 92 per cent and a white cell count of 7,800, with neutrophils 84 per cent, little lymphocytes 13 per cent, great lymphocytes 1 per cent and irritation form 2 per cent, but basophilic and eosinophilic white cells were not found. The urine sediment contained numerous red cells and crystals of acethyl sulfonamide. No special findings were noted on the other examination.

From these point of views, it is rather difficult for us to decide this case as simply toxical reaction or to allergic reaction.

\title{
TWO CASES OF ANURIA DUE TO SULFAMERAZINE.
}

\author{
Katsu Takenouchi and Toshio Takizawa. \\ Dermato-Urology Department, Medical Faculty, University of Chiba.
}

(Directcr Prot. J. Namiki)

In Japan we have few reports about sulfonamide anuria especially, none but one case reported by Takayasu about sulfamerazine anuria. We want to report sulfamerazine anuria which we saw recently. Two cases were observed.

Case 1: Miss. W., 23 years old, farmer, admitted the hospital to have treatment of feces fistula. About eight years ago she had appendectomy and recently the opearation's wound turned to feces fistula. The patient was operated but the operation's wound being suppurated, the patient was given Romezine (Sulfamerazine) on March 24, $3 \mathrm{gm}$; on 25, $5 \mathrm{gm}$; on 26, $2 \mathrm{gm}$; thus the patient was given Romezine totally $10 \mathrm{gm}$ in 3 days. On March 27 the patient began to show oliguria, her total urinary output during the day was only $200 \mathrm{cc}$. The next day, following measures were given in consideration 
of toxicity of drug: injections of Ringer's mixture and glucose solution, and administration of diuretics. Her response to the measure was poor and the patient passed no urine. The following day, the patient visited our clinic (Urologic section). On examination, special findings were not noted in her chest, but there were rigidity and dull pain in the right loin. The patient complained of lumbago and loss of appetite, but had not nausea and vomiting; pulse 120, temperature $101 \mathrm{~F}$. Cystoscopy was performed. There was only a small quantity of bloody urine, but no evidence of crystal formation. It was noted that both orifices were pulled up and excreted no urine. Indigocarmine failed to appear in 10 minutes. Catheters were retained in situ and renal pelves were lavaged with warm water.

The patient responsed to these treatment rapidly, during the day she voided $-200 \mathrm{cc}$ of urine, the next day $400 \mathrm{cc}$. Thus the patient recovered rapidly, a few days later microscopic hematuria disappeared. The catheters were removed 2 days later and on April 22, the patient was discharged.

Case 2: Mr. Y., 52 years old, business man, $1.5 \mathrm{gm}$ and $1 \mathrm{gm}$ of Romezine (6 hours later) were given to prevent infection due to gingivitis which had been operated on Feb. 28. On March 1, he was given $1 \mathrm{gm}$ of Romezine in the morning and $1.5 \mathrm{gm}$ in the evening, iwhich was followed by hematuria the next morning. He was careless enough to take further $1.5 \mathrm{gm}$ during the day. After that he began to feel lumbago and dull pain in the right side of abdomen. The patient began to show oliguria, and afternoon about $80^{\prime}$ clock he voided urine mixed 'with blood clots. A physician was called and diagnosed as acute sulfonamide intoxication and the patient was reffered to our clinic immediately.

On examination, his general condition was not remarkable. Both kidneys were not palpable. Cystoscopy was performed, there was only $5 \mathrm{cc}$ of urine tinted with red, and microscopically there were many red blood cells, There was no evidence of crystal formation and bladder was normal in appearance. At right ureteal orifice there was blood coagulum. Both ureters excreted no urine. Indigocarmine failed to appear in 10 minutes. Catheter passed easily to the right kidney and considerable amount of urine tinged with blood flowed out. However, catheter was obstructed at the left side about $1 \mathrm{~cm}$ from orfice. Efforts were made to pass the catheter and a few [minutes later it passed to the kidney, followed by muddy crystal urine. Catheter were retained in situ. Special finding was not noted in urinary tract.

The pelves were lavaged with warm sodium bicarbonate ( 5 per cent), glucose, and Ringer's solution were injected subcutaneously. Diuretics, cardiotonics and hemostastics were given (campher, coff. natr. benzoic., urocampher, Thrombogen, vitamin $\mathrm{P}$ and $\mathrm{K}$ etc).

Relieved the ureteral catheterization the anuria, we gave him large quantity of water. The patient voided $1600 \mathrm{cc}$ of urine the next day, and two days later $2000 \mathrm{cc}$. His gene- 
ral condition was rapidly improved. Catheters were removed 3 days later. Penicillin was injected for the purpose of protecting urinary infection.

Results of examinations in both cases:

1. Serum reactions for syphilis were negative.

2. Examination of blood showed some changes in blood figure, blood pressure and its content of nonprotein nitrogen, which were improved rapidly according to his recovery.

3. Examination of liver function showed normal.

4. Examination of the kidneys; hematuria, crystalluria and anuria were shown, however, albumin and renal cast were not found in urine.

\section{COMMENT}

As to sulfonamide anuria several reports were seen in recent "American literature. Shapiro, Kleimann reported sulfathiazole anuria and in their cases they urged the importance of early decapsulation. Wishard, Hammer, and Mertz reported sulfadiazine anuria, peritonealdialysis was undertaken for their cases after decapsulation appeared to have failed. There are some other reports by Abeshouse and Hegewann (anuria, crystalluria, hematuria).

Both of these two operations (decapsulation and peritonealdialysis) seemed to have some effects. But we must admit that these have been many unfortunate cases of anuria (toxic, unobstructed) which could not have been relieved even with these operations.

Sulfamerazine is said to have less toxicity on the renal tubules because of its high solubility and less acetilization than other sulfonamide compounds. So far as our cases are concerned, we do not think sulfamerazine dosis taken by our patients were not proper. However, the patients began to show hematuria, oliguria and anuria within 2 or 3 days, which could be relieved fortunately by lavage of the pelvis alone.

It is obvious, therefore, that there are some toxic reaction on renal tubules caused by sulfamerazine which in general were thought to be less toxic than other sulfonamide compounds.

Lehr reported recently that one could lessen the troublesome side-effects of sulfonamide and keep proper blood concentration of the drug by using mixed sulfonamide compounds. We have some data in connection with the administration of sulfonamide mixture, and we will report some of them in future.

\section{CONCLUSION}

1. We have reported two cases of anuria due to sulfamerazine.

2. These two cases showed to have been recovered rapidly by lavage of the pelvis and administration of diuretics and heart stimulants.

3. Our above two cases caused anuria in spite of the fact that sulfamerazine has less toxicity than other sulfonamide compound (though its dosis is observed to be proper). We urged, therefore, that care always should be given when we administrate sulfamerazine.

Unfortunately, if anuria should occur, we believe the principle of therapy must be performed step by step. 1. Lavage of pelvis and washing with warm sodium bicarbonate 
water. 2. Decapsulation and pyelectomia of the kidney. 3. Intraperitoneal irrigation. (We wish to thank our Director Prof. J. Namiki, for his invaluable help and advice.)

\title{
スロン(需國臟器製合成女性ホルモン)の大量 投與による前立腺癌の治療
}

\author{
東京大學䜿學部泌尿器科教室

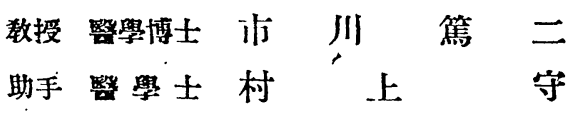

T, Ichikawa \& M. Murakami: Treatment of the Prostatic Cancer with "Suron(Hexoesterol)" in Large Dosis.

\section{緒言}

前立腺癌に對する抗男性ホルモン療法 Antiandrogenic therapy は最近の冈分泌學の治療方面 に於ける大發罗の1つである。本療法は女性ホル モンの投與と, 除睪石という2つの形式で行われ 乃.

此の抗男性ホルモン療法は Huggins の创案し たものとして知られているけれ共，彼より以前に 試みた人がある。即ち Strohm（1935）は除睪润 により，Counsler（1936）は睪丸のレ線照射によ り，又 Kahle \& Maltry（1940）は女性發情物質 の投與により前立腺癌の呈する臨床症岲を輕快せ しめ得たことを報告したか，㑉々の症例報告の域 を脫しなかつたをめに一般の注目を惹くに到らな かつた.

所が Huggins (1941) が女性發情ホルモン投與 及び去等乪によつて行つた前立胍癌治療のまとま つた成績を發表したのを機會に一躍世の注目を浴 び歐米に於ては忽ち廣く追試研究され本潦法の效 果が歌歌されるに至つたのである，歐米に於てか くる速かに本療法が宣俱されるに至つたのには理 由があるのであつて，例えばアメリカに就てみて も，每年約 8000 人が前立腺癌のために死亡し本症 は男性の癌として胃癌に次ぐ重要なすのであるの
である.アメリカ人男子 50 歲以上のもの 前立 を組織學的に精查すると $30 \%$ 於て本症の萠芽 もいうべき變化が見られ，此の變化出現の陽性: は更に年䍅と共に增加するのである，只此の萠： の發育の速度に大きな差があり，發育速度の崌 そめに生前臨休症狀を發現しないで終るるのが. 較的に多いといわれている.

我か國に於ては抗男性ホルモン療法の研究は メリカに比較すると诰だ盛んでないがこれば 立泶癌患者が歐米より少いことが大さな原因で ることは間違いない所である，然しながら我が に於ける本症も以前に考えられていた程稀な疾。 ではなく；我か漖室に於ても從前は數年閒に 11 をみる程度であつたのであらか，最近的 2 年間! 手術及び剖檢によつて本症の確認されたるのだ でも10例を越える状濯で，直腸內觸診所見のみ; ら本症を疑う患渚まで數えれば更に多く，血清 オスフアダーゼの定量, レ線渗断，前立腺分泌中 の細胞學的診斷(Papanicolaou)更に試驗切片の主 取等が普及すれば，我が國に於ける本症患者はシ して今迄考えられていた程少いるのではなく， つて抗男性ホルモン療法の恩惠に浴する患者が なり㙁州するものと思われる。

本療法は根治手街の不可能な前立腺癌に對し。 